\title{
The Development of Learning Model Through Problem Based Introduction (PBI) on Student's Motivation Improvement in Mathematics Education
}

\author{
Surya Wisada Dachi',a, Ismail Hanif Batubara ${ }^{1, b}$ \\ 1Department of Mathematics Education, Faculty of Teacher Training and Education, University of Muhammadiyah Sumatera Utara, Indonesia \\ a suryawisada@umsu.ac.id; b ismailhanif@umsu.ac.id \\ *Corresponding Author \\ Whatsapp Number [085761175181]
}

How to Cite: Dachi, S.,W., Batubara, I.,H. (2020). The Development of Learning Model Through Problem Based Introduction (PBI) on Student's Motivation Improvement in Mathematics Education. International Journal for Educational and Vocational Studies, 2(2), 174-177. DOI: https://doi.org/10.29103/ijevs.v2i2.2284

\section{ARTICLE HISTORY}

Received:11 November 2019

Revised: 21 December 2019

Accepted: 20 January 2020

\section{KEYWORDS}

Learning Model;

Problem-Based Introduction;

Student's Motivation Improvement;

Mathematics Education;

\begin{abstract}
The formulations of the study conclude into two aspects, that are: (1) How effective problem-based introduction (PBI) model for mathematics education students' motivation FKIP UMSU; (2) Does the learning model through Problem-Based Introduction provides a significant improvement on students' motivation. The objectives of this study were: (1) To determine the effectiveness of the problem-based introduction (PBI) model on mathematics education students' motivation in FKIP UMSU, (2) To increase the motivation for mathematics education students to FKIP UMSU through a problem-based introduction (PBI) model. From the results of the research carried out by developing a learning device based on a problem-based introduction (PBI) model to improve the learning motivation of mathematics education students at FKIP UMSU. From the hypothesis calculation data obtained $t$ count $>t$ table is $4,803>2,005$ so that $\mathrm{Ho}$ rejected and $\mathrm{Ha}$ is accepted.
\end{abstract}

This is an open access article under the CC-BY-SA license.

\section{INTRODUCTION}

The low rank of students' motivation and learning outcomes precisely in mathematics are not solely because of challenging material but can also be caused by the learning process carried out. In the mathematics learning process, the students still using the old paradigm in learning in the sense of maternal learning, and also monotonous communication. In other words, teachers tend to transfer the knowledge directly to the students. Finally, students didn't get anything and just waiting for teacher instruction.

Therefore, in the mathematics learning process, teachers should prefer a variety of approaches, strategies, methods, and models that are appropriate to the situation. So the planned learning objectives will be achieved. A Teacher must use model and learning design that can emphasize student learning activities. So it is crucial for teacher assured re-design teaching aid to provides the most comprehensive opportunity in building students' knowledge. From the statement, the writer expected that learning outcomes and learning motivation could be better achievements.

Learning models are usually compiled based on various principles or theories as a foothold in their development. According to Slavin (2010), the learning model is a reference to a learning approach, including goals, syntax, environment, and management system. The learning model can be used as a pattern of choice, meaning that the teacher may choose the appropriate and efficient learning model to achieve the learning objectives.

Problem Based Instruction (PBI) is one of many innovative learning models. This learning model presents a learning condition active students involve students in a problem solving through the stages of the scientific method. Through this PBI, students are expected to be able to learn knowledge related to the issues presented and can have a skill in solving problems. In other words, Kurniasih (2015, p. 48) states that the problem-based instruction learning model in principle, the primary purpose of this learning is to explore the students' creativity in thinking and motivating students to continue learning. 
Precisely, the PBI learning model aims to assist students in developing students thinking skills and problem-solving skills. Authentically learning adult roles, becoming independent students, to drive at a more general level of mentality, making the possibility of transferring new knowledge, developing critical thinking, and creative skills, improving problem-solving skills, increasing student learning motivation, helping students learn to transfer knowledge to new situations. Kurniasih (2015, p. 48).

Those fundamental function of PBI's learning is to help students develop their thinking skills and problem-solving skills. Students try to think critically and can improve their analytical skills and become independent learners. Furthermore, the benefits of PBI are designed to achieve goals for instance investigating, understanding, and helping students become independent learning, thus making them think about the problems and types of information needed to solve the problem.

The implementation of $\mathrm{PBI}$ is expected to be able to train students' critical thinking skills and learning motivation. Motivation in the learning process is necessary for acceleration in achieving specific educational and learning goals. Hence, motivation is included in the individual where there is an urge to do something to achieve the goal.

According to Santrock in Kompri (2015: 3), motivation is a process that provides enthusiasm, direction, and persistence of behavior. It means that behavior that is full of energy, directed and enduring. Whereas according to Mc. Donald in Sardiman (2014: 74), motivation is "a change in energy in a person that is characterized by the appearance of feeling and preceded by a response to a goal." From understanding, Mc. Donald in Sardiman A. Mini contains three essential elements, namely:

a. Motivation begins the change of energy in every human being

b. Motivation marked by the appearance of one's feelings and affections

c. Motivation will stimulate because of the purpose. So motivation, in this case, is a response to an action that is a goal.

Besides, there is another function of motivation, which is to provide a separate value or intensity of a student in increasing learning motivation and learning achievement. While according to Suprijono (2009: 165) provides three motivational functions, namely:

a. Assist people to act, so as a driver or instrument that releases energy. In this case, motivation is the driving force of every activity that will be carried out.

b. Restrict the direction of action, namely towards the goal. Thus motivation can provide guidance and activities that must be done according to the objectives

c. Selecting steps, determining what actions should be done in harmony to achieve the goal, by setting aside activities that are not beneficial for that purpose.
In teaching and learning activities, the role of intrinsic and extrinsic motivation is vital. According to Sardiman AM (2014: 92-95), several forms of ways to grow motivation in learning activities, namely:

1) Giving Numbers. Numbers in this case as a symbol of the value of learning activities.

2) Prizes. Giving a prize can be a powerful learning motivation for students.

3) Competition. Whether individual or group, can be a means to increase learning motivation.

4) Ego-involvement. Growing awareness of students to feel the importance of the task and accept it as a challenge, so working hard is one of the critical forms of motivation.

5) Remedial. Providing students who are experiencing learning difficulties.

6) Knowing the Results. Knowing the results of learning can be used as an instrument for students' learning motivation

7) Praise. To express warm approval or admiration to students who are succeed in completing their assignments properly, it needs to be given praise.

8) Punishment. A negative form of reinforcement, but if given correctly and wisely, it can be a tool for children's learning motivation.

\section{MATERIALS AND METHODS}

This study conducted to the Mathematics Education Study Program in the Teacher Training and Education Faculty (FKIP) of University Muhammadiyah of Sumatera Utara (UMSU). It is located at Jalan Kapten Muchtar Basri No. 3 Medan. The population in this study were the Fifth semester of the mathematics education study program, which was consisted of 5 classes. The sample in this study amounted to 2 classes taken randomly, experimental class and control class.

There are two variables in the quantitative experimental method, namely independent variables, and dependent variables.

1. The independent variable in this study is the development of learning devices of problem-based introduction models

2. The dependent variable of this study is student learning motivation in learning by using a problem-based introduction model.

The research instrument is in the form of Pre-Test and Post-Test given to students and also observations made by researchers during the learning process. The data analysis technique is the prerequisite test: (1) normality test, (2) testing the hypothesis. To see the learning model through Problem Based Introduction on students' motivation improvement. 


\section{RESULTS AND DISCUSSIONS}

\subsection{Introductory Data Analysis}

The introductory knowledge test provided before using a problem-based introduction (PBI) model to see the initial population analysis on the initial knowledge test (Pre-Test).

Table 1. Introductory Test

\begin{tabular}{|c|c|c|c|c|c|c|}
\hline & $\mathrm{N}$ & Minimum & Maximum & \multicolumn{2}{|c|}{ Mean } & Standard Deviation \\
\hline & Statistic & Statistic & Statistic & Statistic & Std. Error & Statistic \\
\hline $\mathrm{X} 1$ & 28 & 30 & 80 & 44.25 & 2.229 & 11.793 \\
\hline $\mathrm{X} 2$ & 28 & 20 & 70 & 40.29 & 2.221 & 11.753 \\
\hline Valid N (listwise) & 28 & & & & & \\
\hline
\end{tabular}

Data Normality Test

To find out the normality of a test used is Kolmogrov

Smirnov as in the table 2.

Table 2. Normality Using the PBI Model and Learning Motivation

\begin{tabular}{|c|c|c|c|c|c|c|}
\hline & \multicolumn{3}{|c|}{ Kolmogrov-Smirnov } & \multicolumn{3}{|c|}{ Shapiro-Wilk } \\
\hline & Statistic & Df & Sig. & Statistic & Df & Sig. \\
\hline $\mathrm{X} 1$ & .119 & 28 & .200 & .956 & 28 & .287 \\
\hline X2 & .113 & 28 & .200 & .960 & 28 & .344 \\
\hline
\end{tabular}

In table 2 , it shows that $\mathrm{L}_{\text {count }}$ and $\mathrm{L}_{\text {Table }}$ analyze the normality test of variables $\mathrm{X} 1$ and $\mathrm{X} 2$ as the table 3 .

Table 3. Normality Test Analysis X1 and X2 Variables

\begin{tabular}{cccc}
\hline Variable & $\mathrm{L}_{\text {Count }}$ & $\mathrm{L}_{\text {table }}$ & Description \\
\hline $\mathrm{X} 1$ & 0,0798 & 0,167 & Normal \\
\hline $\mathrm{X} 2$ & 0,1379 & 0,167 & Normal \\
\hline
\end{tabular}

Based on the table above that $\mathrm{L}_{\text {Count }}<\mathrm{L}_{\text {table }}$ is the test using the PBI model is $0.0798<0.167$ and in the learning motivation test using the PBI model is $0.1379<0.16$.

\section{Testing the Hypothesis}

From the data it is accomplished $t_{\text {Count }}=4.803$. Next, compare the price of tcount to $t$ table. with $\mathrm{dk}=\mathrm{n} 1+\mathrm{n} 2-2$ which is $\mathrm{dk}=28+28-2=54$ and the error rate used is 0.05 so that the price of $t$ Table $=2.005$ is obtained. Because $t_{\text {count }}>t$ table is $4.803>2.005$, so H0 is rejected and $\mathrm{Ha}$ is accepted. It means that there is significant improvements in the use of the Problem-Based Introduction (PBI) model to increase the learning motivation of FKIP UMSU mathematics education students.

\section{DISCUSSION}

Based on the results of the research carried out by The Development of Learning Model Through PBI On Students' Motivation Improvement in Mathematics Education. The results of this study show the hypothesis testing provides a significant effect entirely. The average of PBI proves the model gained a more excellent score than the traditional method in teaching and learning in the classroom. For the average value using a PBI model to increase the learning motivation of mathematics education students, which is 77.43 with the highest score is 95 and the lowest score is 60 and the standard deviation of 10.105. On the other hand, the students' score average which not using PBI model to increase the learning motivation of mathematics education students is 63.10, with the highest score is 90 , and the lowest score is 45 and the standard deviation of 10.850 . This shows that the PBI model to increase the learning motivation of Mathematics Education students is "effective."

\section{CONCLUSION}

The results of the study provide a significant effect on the development of the learning model through Problem Based Introduction (PBI) On Students' Motivation Improvement in Mathematics Education FKIP UMSU. Based on the Hypothesis Test $t_{\text {count }}>t_{\text {table }}$ is $4.803>2.005$, so $\mathrm{Ho}$ is rejected, and $\mathrm{Ha}$ is accepted. In other words, that there is a significant increase in the learning model through Problem Based Introduction (PBI) On Students' Motivation Improvement in Mathematics Education FKIP UMSU.

\section{Recommendation}

The writer expected that the Development of Learning Model Through Problem Based Introduction (PBI) On Students' Motivation Improvement might give contribution both theoretically and practically. Theoretically, the learning model can be implemented as teaching references in the classroom. And hopefully, the PBI can encourage teacher, lecturer, and students give more inspiration to the teaching and learning activity. Batubara, IH (2017: 103) states that the improvement of students' critical thinking skills taught through Geogebra-assisted problem-based learning is higher than those taught through geogebra-assisted problem-based learning. Practically, the writer expected the development 
of the learning model through PBI will be redesign and reinvented in future research.

\section{REFERENCES}

A.M, Sardiman. (2014). Interaksi dan Motivasi Belajar Mengajar. Jakarta: Rajawali

Batubara, IH. (2017). Increased Ability to Understand Mathematical Concepts Through Geogebra and Geogebra-Assisted Problem-Based Learning Models at Free Methodist Medan. Journal of Mathematics Education and Science. Volume (3) 47-54.

Kurniasih, Imas. (2015). Ragam Pengembangan Model Pembelajaran. Jakarta: Kata Pena.

Kompri. (2015). Motivasi Pembelajaran Perspektif Guru dan Siswa. Bandung: PT. Remaja Rosdakarya.

Suprijono Agus. (2010). Cooperative Learnin. Surabaya: Pustaka Belajar.

Sudjana. (2002). Metode Statistika Untuk Penelitian. Bandung: Alfabeta. 